\title{
Radioimmunoassay of Growth Hormone-dependent Insulinlike Growth Factor Binding Protein in Human Plasma
}

\author{
Robert C. Baxter and Janet L. Martin \\ Department of Endocrinology, Royal Prince Alfred Hospital, Camperdown, New South Wales 2050, Australia
}

\begin{abstract}
A specific radioimmunoassay has been established for a growth hormone-dependent insulinlike growth factor (IGF) binding protein (BP) from human plasma. Although the assay was directed against a 53-kD, acid-stable $B P$ subunit, the main immunoreactive BP in the circulation had an apparent molecular mass of $\sim 125 \mathrm{kD}$. Only higher primate species showed crossreactivity, and IGF-I, IGF-II, and other peptides were without effect. Circulating BP levels in healthy subjects rose threefold from early childhood to puberty. In 65 adults aged 18 to 65 , the mean level $( \pm S D)$ was $6.12 \pm 1.43 \mu \mathrm{g} / \mathrm{ml}$, and declined with age. Strong growth hormone-dependence of BP was also seen; there was a 2.2-fold increase in active acromegaly and a 50-80\% reduction in growth hormone deficiency. Poorly controlled diabetic subjects had BP levels $\mathbf{4 0} \%$ below normal, whereas in renal failure and third-term pregnancy a mild elevation was seen. Measurement of BP may provide a useful adjunct to IGF assays in growth disorders.
\end{abstract}

\section{Introduction}

The existence of circulating binding proteins for peptides of the insulinlike growth factor (IGF) ${ }^{1}$ family has been recognized for almost a decade $(1,2)$. At least two such proteins have been identified by radioligand binding studies: one, a growth hormone (GH)-dependent protein of an approximate molecular mass of $150 \mathrm{kD}$, which carries most of the endogenous IGF peptides (3-5), and the other, a protein of 30-35 kD which accounts for most of the unsaturated binding sites in plasma (4) and may be inversely regulated by $\mathrm{GH}(4,6)$. Several other binding species, with molecular masses ranging from 24 to $160 \mathrm{kD}$, have also been found in affinity labeling experiments (7). The ability to quantitate these proteins is vital to a complete understanding of growth regulation by the IGFs, since changes in their concentrations will affect the size distribution, and perhaps the availability to tissues, of the circulating growth factors. In addition, as both proteins may, directly or inversely, reflect GH status, their measurement could provide information of value in the diagnosis and monitoring of growth disorders.

Address correspondence to Dr. Baxter.
Received for publication 17 January 1986 and in revised form 28
July 1986.

1. Abbreviations used in this paper: $\mathrm{BP}$, binding protein; $\mathrm{GH}$, growth hormone; IGF-I and IGF-II, insulinlike growth factors I and II; IR-BP, immunoreactive BP.

J. Clin. Invest.

(C) The American Society for Clinical Investigation, Inc.

0021-9738/86/12/1504/09 \$1.00

Volume 78, December 1986, 1504-1512
The 35-kD unsaturated binding protein (BP) is related immunologically to an IGF BP of similar size isolated from human amniotic fluid (8), and has recently been measured by radioimmunoassay (RIA) using antibodies raised against the amniotic fluid protein $(6,9)$. Quantitation of the larger protein has proved to be more difficult, as the binding of radioligands is severely inhibited due to binding site occupancy by endogenous IGFs. Although this protein has been measured after removal of bound ligands by gel permeation chromatography at low pH (10-12), this treatment results in the irreversible breakdown of the 150$\mathrm{kD} \mathrm{BP}$ to a relatively stable form of $50-60 \mathrm{kD}(13,14)$. We recently described the purification of an acid-stable $\mathrm{BP}(15,16)$, and identified a major glycoprotein component of an apparent molecular mass of $53 \mathrm{kD}$, and a minor component of $47 \mathrm{kD}$, by polyacrylamide gel electrophoresis. A rabbit antiserum raised against this BP preparation reacted with a human plasma protein corresponding on gel permeation chromatography with gamma globulin, presumably the $150-\mathrm{kD}$ BP (15). The present report provides a detailed description of the RIA for IGF BP using this antiserum, and describes variations in the circulating levels of this protein in healthy subjects throughout life, and in a variety of their pathological states.

\section{Methods}

$B P$. Acid-stable BP was isolated from Cohn fraction IV of human plasma by affinity chromatography on agarose-IGF-II and reverse-phase high performance chromatography, as described previously $(15,16)$. Sodium dodecyl sulfate polyacrylamide gel electrophoresis revealed a major band of $53 \mathrm{kD}$ and a minor band of $47 \mathrm{kD}$, unreduced, or $43 \mathrm{kD}$ and $40 \mathrm{kD}$ respectively, reduced. Both bands could be stained for protein and carbohydrate (16). In the present paper, this preparation is simply referred to as $53 \mathrm{kD}$ BP. Initial structural studies indicated a single residue, glycine, at the amino-terminus (16), and an amino acid composition and unambiguous amino-terminal decapeptide different from that of the amniotic fluid binding protein (16a). All of the binding sites for IGF-I or IGF-II in this BP preparation could be precipitated by concanavalin A (16), which indicated that the 35-kD serum BP, which does not bind to concanavalin A (7), was not present. Binding data obtained with the purified BP were consistent with the existence of a single binding site for IGF-I or IGF-II per 53-kD protein, with a slightly higher binding affinity for human IGF-II than for human IGF-I (16).

Other proteins and peptides. Human IGF-I and IGF-II were isolated from Cohn fraction IV as previously described (17). Human amniotic fluid BP was isolated by affinity chromatography on an agarose-IGF-I column (16a). Its apparent molecular mass by analytical polyacrylamide gel electrophoresis was 28-30 kD, and its amino-terminal sequence, determined by Drs. M. Tyler and M. Howden, School of Chemistry, Macquarie University, Sydney, Australia, was Ala-Pro-Trp-Gln-X-Ala-ProX-Ser-Ala (positions 5 and 8 not determined), which was identical to that reported for the previously purified protein (18). Human albumin, prolactin, luteinizing hormone, and follicle stimulating hormone were obtained from Calbiochem-Behring Corp., San Diego, CA, human transferrin from Sigma Chemical Co., St. Louis, MO, human growth hormone from Commonwealth Serum Laboratories, Melbourne, Aus- 
tralia, human insulin from Novo, Copenhagen, Denmark, and human placental lactogen from the National Hormone and Pituitary Program, Bethesda, MD. Bovine albumin was Sigma RIA grade.

Tracers. The routine BP RIA, described below, used as tracer a covalent complex of ${ }^{125} \mathrm{I}-\mathrm{IGF}-\mathrm{I}$ and $53-\mathrm{kD} \mathrm{BP}$, and was prepared as follows. Human IGF-I (5.6 $\mu \mathrm{g}$ in $50 \mu \mathrm{l} 0.5 \mathrm{M}$ sodium-phosphate buffer, $\mathrm{pH} 7.4$ ) was reacted at $22^{\circ} \mathrm{C}$ in a siliconized glass tube with $2 \mathrm{mCi}$ sodium ${ }^{125} \mathrm{I}$ (Amersham Int'l., Amersham, United Kingdom) in the presence of 10 $\mu \mathrm{g}$ chloramine-T. After $20 \mathrm{~s}$, sodium metabisulfite, $50 \mu \mathrm{g}$ in $10 \mu \mathrm{l}$ phosphate buffer, was added, and unreacted radioactivity was removed by chromatography on a $1 \times 30$-cm Sephadex G-50 (fine) column equilibrated and eluted with $0.05 \mathrm{M}$ sodium-phosphate buffer, $\mathrm{pH}$ 6.5, containing $0.25 \%$ bovine albumin. In four similar iodinations, the incorporation of iodine into IGF-I was $73 \pm 5 \%$ (mean \pm SD), which gave a mean estimated specific activity of $220 \pm 14 \mathrm{Ci} / \mathrm{g}$, and an approximate iodination ratio of $0.75 \mathrm{~mol} / \mathrm{mol}$ IGF-I. To form the covalent BP-IGFI complex, $1 \mu \mathrm{g}$ iodo-IGF-I $(0.22 \mathrm{mCi})$ in $1 \mathrm{ml}$ column buffer was added to a tube containing $8 \mu \mathrm{g}$ pure BP, and allowed to react for $2 \mathrm{~h}$ at $22^{\circ} \mathrm{C}$. Disuccinimidyl suberate (Pierce Chemical Co., Rockford, IL) in $10 \mu \mathrm{l}$ dimethylsulfoxide was added to a final concentration of $0.25 \mathrm{mM}$, and after a further $30 \mathrm{~min}$ at $22^{\circ} \mathrm{C}$, the reaction was terminated by the addition of $50 \mu \mathrm{l} 1 \mathrm{M}$ Tris chloride, $\mathrm{pH}$ 8.0. Unreacted iodo-IGF-I was separated from the BP-IGF-I complex by chromatography on a $1 \times 40-\mathrm{cm} \mathrm{Se}-$ phadex G-100 column, equilibrated and eluted with $0.5 \mathrm{M}$ acetic acid, $0.1 \mathrm{M}$ sodium chloride, and $0.25 \%$ bovine albumin, adjusted to $\mathrm{pH} 3.0$ with sodium hydroxide. The mean cross-linking efficiency in four preparations was $40 \pm 11 \%$, which gave typical specific activities of $10-12 \mathrm{Ci} /$ $\mathrm{g}$ or $0.3 \mathrm{~mol}$ iodine per mol BP-IGF-I. A covalent BP-IGF-II complex, used in some preliminary experiments, was produced in a similar way. To radioiodinate BP directly, $8 \mu \mathrm{g}$ pure protein was reacted with $1 \mathrm{mCi}$ sodium ${ }^{125}$ I under conditions identical to those used for IGF-I iodination, and unreacted radioactivity was removed by gel chromatography at $\mathrm{pH}$ 3.0, exactly as described for the BP-IGF-I complex.

$B P R I A$. The RIA for IGF BP was performed in $10 \times 75-\mathrm{mm}$ polystyrene tubes, in a buffer containing $0.1 \mathrm{M}$ sodium phosphate, $\mathrm{pH} 6.5$, $0.02 \%$ sodium azide, and $0.25 \%$ bovine albumin. Incubation mixtures ( $500 \mu$ l total volume) consisted of appropriately diluted samples or standards $(50 \mu \mathrm{l})$, antiserum R1-4 (15) diluted 1:1,000 (100 $\mu \mathrm{l})$, BP-IGF-I tracer, $10,000 \mathrm{cpm}$ or $0.5 \mathrm{ng}(100 \mu \mathrm{l})$, and assay buffer $(250 \mu \mathrm{l})$, added in that order and vortex mixed. The standard range was 0.1 to $20 \mathrm{ng}$ of pure BP, or 0.01 to $5 \mu \mathrm{l}$ of a reference pool of normal human plasma described below. Patient samples were routinely assayed in duplicate at $0.25 \mu \mathrm{l}$ per tube, added as $50 \mu \mathrm{l}$ of a 1:200 dilution in assay buffer. In preliminary studies it was observed that serum or plasma gave identical results.

After $16 \mathrm{~h}$ incubation at $22^{\circ} \mathrm{C}, 1 \mu \mathrm{l}$ normal rabbit serum and $50 \mu \mathrm{l}$ goat anti-rabbit immunoglobulin ( $\mathrm{Tg}$ ) (Bio-RIA, Montreal, Canada) were added and, after a further 30 -min incubation, $1 \mathrm{ml}$ of ice-cold $6 \%$ polyethylene glycol solution (PEG 6000; Merck Chemical Div., Merck \& Co., Inc., Rahway, NJ) in 0.15 M sodium chloride was added, and tubes were centrifuged $20 \mathrm{~min}$ at $4,200 \mathrm{rpm}$ in a Beckman J-6 centrifuge cooled to $2^{\circ} \mathrm{C}$. Supernatants were decanted, and the radioactivity in the pellets determined in a gamma counter. Under the conditions described above, mean specific binding of BP-IGF-I tracer was $21.9 \pm 1.3 \%(\mathrm{SD}, n=10)$ of total radioactivity, and nonspecific binding, measured in the absence of antiserum, was $2-3 \%$ of total. The within-assay imprecision for the means of duplicates, determined by analysis of variance of 20 duplicate pairs at each level, was $6.2 \%$ at $2.5 \mu \mathrm{g} / \mathrm{ml}, 5.5 \%$ at $5.7 \mu \mathrm{g} / \mathrm{ml}$, and $4.5 \%$ at $12.6 \mu \mathrm{g} / \mathrm{ml}$. The between-assay imprecision, calculated from three quality control samples run in 10 assays, was $11.9 \%$ at $2.9 \mu \mathrm{g} / \mathrm{ml}, 14.5 \%$ at $6.3 \mu \mathrm{g} / \mathrm{ml}$, and $13.1 \%$ at $12.7 \mu \mathrm{g} / \mathrm{ml}$.

In some early experiments, a BP-IGF-II complex was used as tracer in place of BP-IGF-I. This gave similar results to those seen in the routine assay, but was not used routinely because iodination yields for IGF-II were always lower than for IGF-I. Radioiodinated BP was also tested for use as tracer, as direct iodination was somewhat more straightforward than affinity labeling for routine tracer preparation. It was found, however, that iodo-BP was inferior to BP-IGF-I as a tracer. This was principally due to a strong tendency for the iodinated protein to adsorb to laboratory ware, even in the presence of albumin. Nonspecific binding with this tracer was invariably high, usually $>15 \%$ of total radioactivity, and much of this binding could be displaced by plasma, although not by excess pure BP, which resulted in nonparallelism between plasma and BP displacement curves. Therefore, although it is not clear why occupancy of the IGF binding site should have such a marked effect on the behavior of the BP, the cross-linked tracer was used in all routine experiments. As preparation of this tracer could easily be achieved in a day, and each batch lasted 4-6 wk with little loss of binding, the slightly less direct preparation method was not considered an obstacle.

Other assay conditions were also optimized in preliminary experiments. Incubation periods up to $48 \mathrm{~h}$ at $22^{\circ} \mathrm{C}$ did not give significantly greater binding or sensitivity than the $16-\mathrm{h}$ incubation finally chosen. At $2^{\circ} \mathrm{C}$, binding was much slower than at $22^{\circ} \mathrm{C}$, so that even after $40 \mathrm{~h}$ tracer binding was less than that seen under standard conditions. However, the relationship between the displacement curves for plasma BP and pure BP (i.e., the amount of plasma BP that could be quantitated) was the same whether incubations were for 16 or $40 \mathrm{~h}$, at $2^{\circ}$ or $22^{\circ} \mathrm{C}$. Several different buffers were tested, over the $\mathrm{pH}$ range 6.0 to 8.0 , before the routine buffer was selected. Phosphate at $0.05 \mathrm{M}$ was found to give slightly lower binding than at $0.1 \mathrm{M}$, but no difference in binding was seen between $\mathrm{pH} 6.5$ and 8.0. As illustrated in the Results, the use of Hepes, and some other organic sulfonate buffers, resulted in severe nonparallelism between pure BP standard and plasma samples. Nonparallelism in Hepes buffer was also seen when iodinated BP was used as tracer.

Under some storage conditions, pure BP standard lost potency quickly, as described in the Results. However a pool of normal adult plasma was found to maintain its potency under a wide variety of conditions. Because of initial uncertainty regarding pure standard stability, this plasma pool was used as a standard refence preparation in some of the assays used in this study. All results are expressed as micrograms of pure BP standard per milliliter plasma. Where the normal plasma pool was used as a refence preparation, values have been converted to micrograms per milliliter using the equivalence factor of $7.0 \mu \mathrm{g} \mathrm{BP}$ per ml plasma pool, the mean value determined from eight assays in which both standards were run (SEM, $0.33 \mu \mathrm{g}$ ).

IGF assays. IGF-I was measured by the RIA method previously described using rabbit antiserum $\operatorname{Tr} 4$ (19), except that a later bleed of the same rabbit, designated antiserum $\operatorname{Tr} 10$, was used at a final dilution of $1: 50,000$. The cross-reactivity of IGF-II in this assay was $1 \%$. IGF-II was measured by radioreceptor assay using ovine placental membranes (17). The cross-reactivity of IGF-I in this assay was $1 \%$.

Effect of added IGFs. To determine the effect of IGF-I and IGF-II added to plasma samples on the BP RIA, aliquots of $0.24 \mathrm{ml}$ plasma from normal, GH-deficient and acromegalic subjects were incubated 2 $\mathrm{h}$ at $22^{\circ} \mathrm{C}$ with $0.24 \mu \mathrm{g}$ human IGF-I, IGF-II, or both together, added in a volume of $24 \mu \mathrm{l}$ to minimize dilution of the plasma. At the end of the incubation period, samples were assayed in the BP RIA at $0.25 \mu \mathrm{l}$ per tube.

High performance gel chromatography. A $1 \times 30-\mathrm{cm}$ Superose 12 column (Pharmacia Fine Chemicals, Uppsala, Sweden) was equilibrated with $50 \mathrm{mM}$ sodium phosphate, $0.1 \mathrm{M}$ sodium chloride, $0.1 \%$ bovine albumin, $\mathrm{pH} 7.0$, at $0.5 \mathrm{ml} / \mathrm{min}$. Fresh human serum $(100 \mu \mathrm{l})$ was applied to the column and eluted under the same conditions. The absorbance at $280 \mathrm{~nm}$ was monitored using a model 441 absorbance detector (Waters Assoc., Milford, MA). Fractions of $0.5 \mathrm{ml}$ were collected, and $10-\mu \mathrm{l}$ aliquots were assayed for BP immunoreactivity. Chromatography at acid pH was performed similarly, using the same buffer adjusted to $\mathrm{pH} 3.0$ with $6 \mathrm{M} \mathrm{HCl}$. Before loading onto the column, serum was acidified to pH 3.0 with $0.5 \mathrm{M} \mathrm{HCl}$ and incubated $2 \mathrm{~h}$ at $22^{\circ} \mathrm{C}$.

Effect of sample acidification on BP RIA. Three acidification/extraction methods were tested for their effect on the BP RIA. In the first, simple acidification with acetic acid, 100- $\mu$ l aliquots of human plasma samples from normal, GH-deficient, acromegalic, and uremic subjects (three samples per group) were mixed with an equal volume of $2 \mathrm{M}$ acetic acid and incubated $30 \mathrm{~min}$ at $22^{\circ} \mathrm{C}$. Samples were neutralized by 
the addition of $120 \mu \mathrm{l}$ of $2 \mathrm{M}$ Tris base before dilution in assay buffer for BP RIA. The second method involved acidification and lyophilization, similar to the method of Bala and Bhaumick (20), in which $100-\mu$ laliquots of plasma were mixed with $10 \mu \mathrm{l}$ of $10 \%$ formic acid, let stand for $2 \mathrm{~h}$ at $22^{\circ} \mathrm{C}$, and lyophilized. Dried samples were reconstituted and diluted in assay buffer for BP RIA. The third method was acid-ethanol extraction performed exactly according to the method of Daughaday et al. (21). In brief, this involves extraction with $4 \mathrm{vol}$ of an HCl-ethanol mixture, centrifugation, and neutralization of the supernatant with Tris base before dilution into assay buffer for BP RIA.

Plasma samples. Plasma samples from healthy subjects were obtained from the Red Cross Blood Bank, Sydney (adults), and from the Royal Children's Hospital, Melbourne, and the Royal Alexandra Hospital for Children, Sydney (children). Samples from subjects with acromegaly and GH deficiency had been submitted to this laboratory for IGF-I estimation. The mean IGF-I value $( \pm S D)$ for the acromegalics was $965 \pm 214 \mathrm{ng} / \mathrm{ml}$ (normal range: 120 to $360 \mathrm{ng} / \mathrm{ml}$ ). The mean IGF-I value for GH-deficient subjects, all of whom had inadequate responses to provocative stimuli for $\mathrm{GH}$, was $43 \pm 26 \mathrm{ng} / \mathrm{ml}$. Chronic renal failure patients were all sampled immediately before routine hemodialysis, in the Department of Renal Medicine at this hospital. The diabetic subjects were an unselected group (mean age $47 \pm 15$ yr, range 30 to 71 ) who attended the Diabetic Outpatients Clinic at this hospital. The criterion for inclusion was a hemoglobin Alc value (determined by high performance ion-exchange chromatography) $>11 \%$ (normal range: 4 to $8 \%$ ). The mean value in the 10 samples used was $13.5 \pm 1.8 \%$. Samples from hypothyroid patients had been submitted to this laboratory for thyroid function testing. The mean age of the subjects was $49 \pm 11$ yr (range 33 to 63), mean thyroxine level $26 \pm 16 \mathrm{nmol} /$ liter (normal range: 60 to $135 \mathrm{nmol} /$ liter), and mean thyrotropin level $40 \pm 19 \mathrm{mIU} /$ liter (normal range: 0 to $5 \mathrm{mIU} / \mathrm{liter}$ ). Amniotic fluid samples and plasma from women in third-term pregnancy were obtained from the Biochemistry and Obstetrics and Gynecology laboratories at this hospital. Samples from nonhuman primates and other species were kindly provided by Dr. D. Church, Department of Veterinary Clinical Studies, University of Sydney.

Patient samples were stored at $-15^{\circ} \mathrm{C}$ before assay. Control specimens with BP values in the low, intermediate, and high regions of the analytical range retained their activity over at least $6 \mathrm{mo}$ of storage. Although a few of the patient specimens had been stored for over a year (i.e., longer than the duration of our long-term stability studies), their BP levels in all cases were within the range seen for recently obtained specimens in the same patient category. BP was also stable for at least a week when plasma was stored lyophilized at room temperature.

Statistical methods. Analysis of variance and linear regression analysis were performed on a HP-9845 desktop computer using programs supplied by Hewlett-Packard Co., Fort Collins, CO. All group means are presented \pm SD unless otherwise stated.

\section{Results}

A typical gel chromatography profile for cross-linked BP-IGFI tracer is shown in Fig. 1. In four tracer preparations, the mean cross-linking efficiency was $40 \pm 11 \%$, which resulted in tracers of $10-12 \mathrm{Ci} / \mathrm{g}$ sp act. As shown in the Fig. 1 inset, sodium dodecyl sulfate (SDS)-polyacrylamide gel electrophoresis and autoradiography of cross-linked tracer indicated a radiochemically pure labeled species corresponding to a molecular mass of $61 \mathrm{kD}$, consistent with $1 \mathrm{~mol}$ of IGF-I (7.5 kD) bound per mol of 53 kD BP. Also shown in Fig. 1 is the specific binding obtained under routine assay conditions (i.e., antibody at 1:5,000 final dilution) with peak fractions from the gel permeation column. Although binding in the presence of a very large antibody excess could not be tested due to the relatively low titer of the antibody, $72-75 \%$ of the radioactivity in the same fractions could be precipitated by antibody at 1:500 final dilution. With normal or excess antibody, binding was essentially constant across the BP-

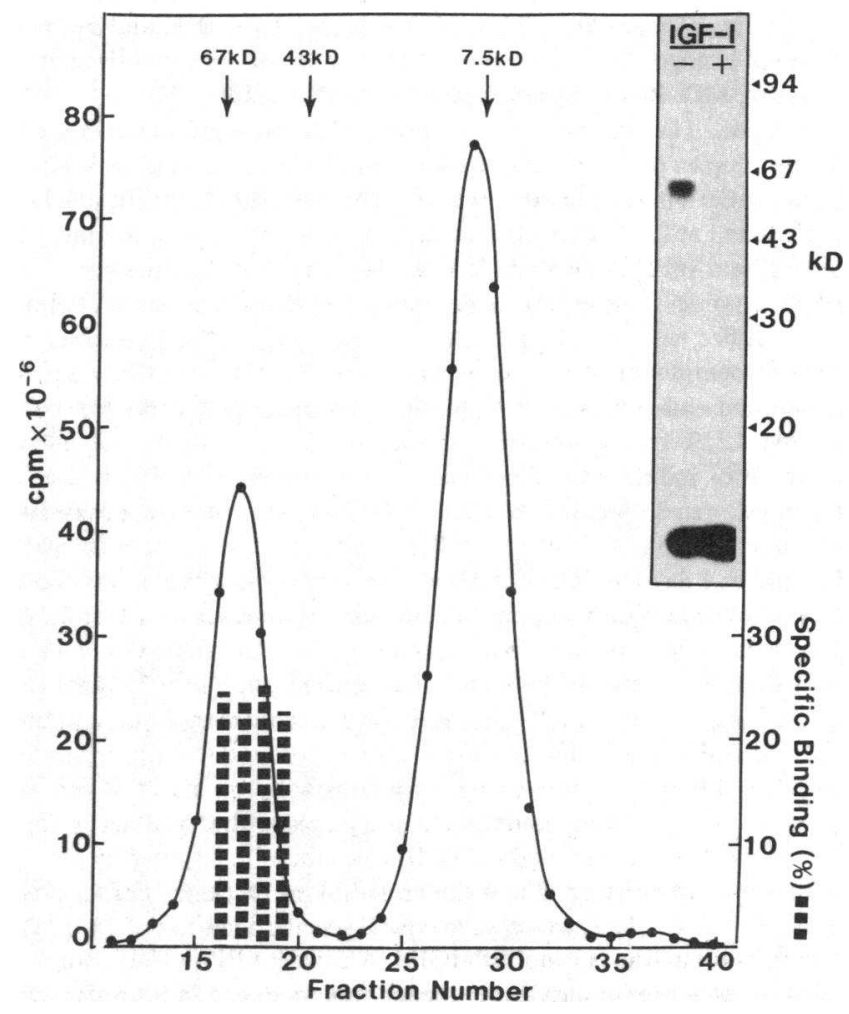

Figure 1. Characterization of BP-IGF-I tracer. Cross-linked tracer was fractionated on a $1 \times 40-\mathrm{cm}$ Sephadex G-100 column in $0.5 \mathrm{M}$ acetic acid, $0.1 \mathrm{M}$ sodium chloride, and $0.25 \%$ bovine albumin, $\mathrm{pH}$ 3.0. Arrows indicate the elution positions of bovine albumin $(67 \mathrm{kD})$, ovalbu$\min (43 \mathrm{kD})$, and IGF-I $(7.5 \mathrm{kD})$. The solid line indicates the radioactivity in each $1-\mathrm{ml}$ fraction. Broken vertical bars represent the specific binding of tracer $(10,000 \mathrm{cpm} /$ tube $)$ in peak fractions $16-19$ to antiserum R1-4 under standard conditions. (Inset) BP affinity labeled in the absence $(-)$ or presence $(+)$ of a 20 -fold excess of unlabeled IGF-I, subjected to SDS-polyacrylamide gel electrophoresis and autoradiography (16). Molecular masses of marker proteins in $\mathrm{kD}$ are indicated. The estimated molecular mass of BP-IGF-I was $61 \mathrm{kD}$.

IGF-I peak, which suggested uniformity of specific activity in each fraction.

In the course of optimizing the conditions for the BP RIA, it was observed that the pure BP standard was very unstable when stored at neutral $\mathrm{pH}$, and also seemed to adsorb to laboratory ware, reducing its activity in solution. In contrast, immunoreactive BP (IR-BP) in plasma appeared completely stable at neutral $\mathrm{pH}$. To obtain reproducible recovery of the pure standard it was stored in $0.5 \mathrm{M}$ acetic acid, $\mathrm{pH} 3.0$, containing $0.25 \%$ bovine albumin, until the time of use. Under assay conditions, the stability or reactivity of the standard appeared much greater in phosphate buffers than in Hepes. Fig. 2 illustrates competitive binding curves using a standard plasma pool and a pure BP standard for assays run in $0.1 \mathrm{M}$ sodium phosphate or $0.1 \mathrm{M}$ sodium Hepes buffers, both at $\mathrm{pH}$ 7.0. Whereas parallelism between the plasma and BP standards was seen in phosphate buffer, the curves were clearly nonparallel in Hepes buffer owing mainly to an apparent severe loss of potency of the pure BP in the high concentration range. A lack of parallelism was also seen when the related buffers TES (2-\{[Tris-(hydroxymethyl)methyl]amino $\}$ ethanesulfonate) or MES (2-( $N$-morpholino)ethanesulfonate) were used at the same $\mathrm{pH}$, but in Tris buffer 


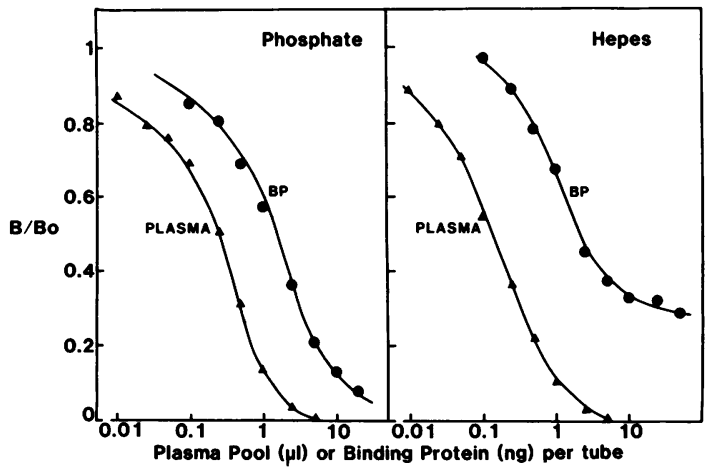

Figure 2. Displacement of bound BP-IGF-I tracer from antibody R14 by increasing concentrations of (solid triangle) pooled normal adult plasma or (solid circle) pure IGF binding protein. (Left) RIA performed in $0.1 \mathrm{M}$ sodium phosphate and $0.25 \%$ bovine albumin, $\mathrm{pH}$ 7.0, exactly as described in Methods. (Right) RIA performed exactly as described in Methods, except that the buffer used was $0.1 \mathrm{M}$ sodium Hepes, $0.25 \%$ bovine albumin, $\mathrm{pH} 7.0$. B/Bo represents the ratio of radioactivity bound in the presence of added plasma or BP to that bound in the absence of additions.

the plasma and BP curves showed parallelism similar to that seen in phosphate. Whether the lack of parallelism seen in the sulfonate buffers is associated with a physical change in the protein is not known. Under the optimal conditions used in the routine assay, half-maximal displacement of BP-IGF-I tracer was seen with $0.293 \pm 0.058 \mu \mathrm{l}$ per tube of normal plasma pool, or $2.26 \pm 0.67 \mathrm{ng}$ per tube of pure $\mathrm{BP}(\mathrm{SD}, n=8)$.

It was previously demonstrated that incubation of a normal plasma sample with $5 \mu \mathrm{g} / \mathrm{ml}$ IGF-I or IGF-II had no effect on its BP immunoreactivity (15). To ascertain whether this was true for all plasma specimens, samples from normal, GH-deficient, and acromegalic subjects were incubated for $2 \mathrm{~h}$ at $22^{\circ} \mathrm{C}$ with pure IGF-I or IGF-II at $1 \mu \mathrm{g} / \mathrm{ml}$ above the endogenous levels, or with both peptides. Table I shows the IR-BP levels in 13 samples treated in this way. When analyzed by two-way analysis of variance, there was a highly significant effect owing to the different plasma samples used $(P<0.0001)$, but no effect due to incubation with either peptide or a mixture of the two $(P>0.1)$. This confirms the previous observation that the RIA is not influenced by either the IGF-I or IGF-II content of the samples.

Fig. 3 compares the IR-BP profiles in normal human serum fractionated on a Superose 12 high performance gel permeation column at $\mathrm{pH} 7.0$ or $\mathrm{pH} 3.0$. At neutral $\mathrm{pH}$, the major peak of immunoreactivity emerged slightly later than the gamma globulin peak, while some activity of smaller molecular size was also evident. Calibration of this column with proteins of known size indicated that the major peak of immunoreactivity was $\sim 125$ $\mathrm{kD}$ in molecular mass, while the "shoulder" of smaller immunoreactive proteins extended down to $25-30 \mathrm{kD}$. In contrast, chromatography at $\mathrm{pH} 3.0$, after incubation for $2 \mathrm{~h}$ at $22^{\circ} \mathrm{C}$ at pH 3.0, resulted in a major peak of IR-BP of apparent molecular mass 55-60 kD, and a significant "shoulder" at 25-30 kD, which was clearly distinguished as a separate peak in several experiments.

The ability of the RIA to detect BP in neutral and acidified plasma was examined in more detail by acidifying specimens from a variety of different subjects, then neutralizing them just before assay. For comparison, two other acidification protocols were also tested, both of which have been used in different lab-
Table I. Effect of Preincubation with IGF-I or IGF-II on the Immunoreactivity of Plasma IGF BP

\begin{tabular}{lcrlr}
\hline & \multicolumn{4}{l}{ IR-BP } \\
\cline { 2 - 5 } Plasma samples & No addition & \multicolumn{1}{l}{ IGF-I } & \multicolumn{1}{l}{ IGF-II } & \multicolumn{1}{l}{ IGF-I + IGF-II } \\
\hline & $\mu g / m l$ & $\mu g / m l$ & $\mu g / m l$ & $\mu g / m l$ \\
Normal (4) & $7.45 \pm 1.46$ & $7.52 \pm 1.79$ & $7.62 \pm 1.88$ & $7.65 \pm 1.85$ \\
GH deficient (4) & $2.33 \pm 1.28$ & $2.73 \pm 1.12$ & $2.76 \pm 1.23$ & $2.88 \pm 1.36$ \\
Acromegalic (5) & $12.59 \pm 1.33$ & $12.58 \pm 1.41$ & $12.60 \pm 1.90$ & $12.83 \pm 1.67$
\end{tabular}

Plasma samples from normal, GH-deficient, and acromegalic subjects were incubated $2 \mathrm{~h}$ at $22^{\circ} \mathrm{C}$ with human IGF-I, IGF-II, or both peptides, to give a final concentration of $1 \mu \mathrm{g} / \mathrm{ml}$ above the endogenous levels. Incubated samples were then assayed for BP by RIA as described in Methods. Values shown are means \pm SD for the number of samples indicated in parentheses. Two-way analysis of variance showed a highly significant effect of patient category on BP levels $(P<0.0001)$, but no effect of incubation with IGF peptides.

oratories to minimize interference by BPs in the IGF-I RIA (20, 21). As shown in Fig. 4, simple acidification and neutralization had no effect on BP immunoreactivity regardless of the type of plasma tested. When samples were acidified and then fractionated on Superose 12 at pH 3.0 (as illustrated in Fig. 3), the mean recovery of activity, obtained by summing all of the active fractions, was $79 \pm 3 \%$ (SD, $n=4)$. The acidification, lyophilization, and reconstitution protocol of Bala and Bhaumick (20) also had relatively little effect on the amount of BP detected by the assay, reducing IR-BP by only 5\% overall in the samples tested (Fig. 4). By far the greatest loss of IR-BP was seen with the acidethanol extraction protocol of Daughaday et al. (21), which caused a mean activity loss of $85 \%$. It is notable, however, that this method does not entirely remove BP from human plasma, as the residual activity was significantly greater than zero for the

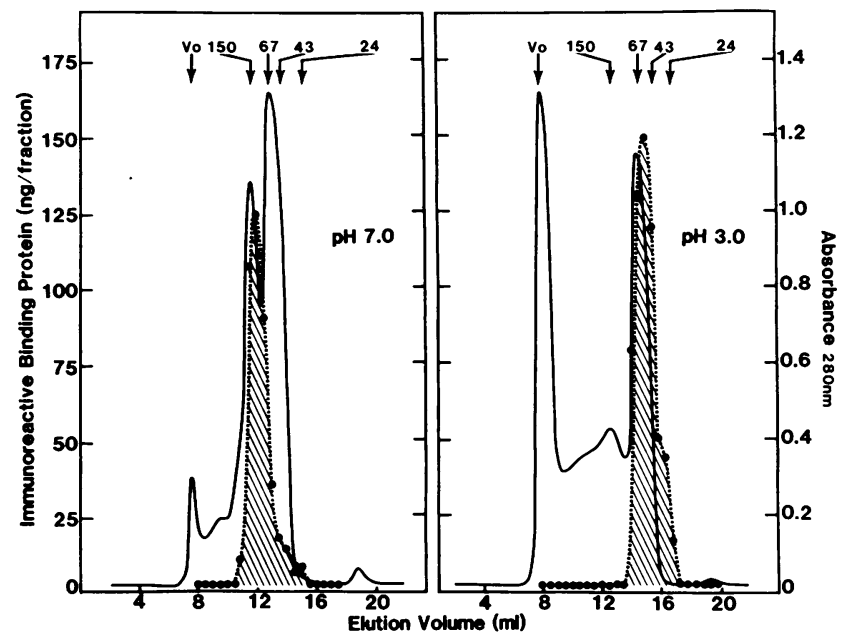

Figure 3. Fractionation of human serum $(0.1 \mathrm{ml})$ by high performance gel permeation chromatography on a $1 \times 30-\mathrm{cm}$ Superose- 12 column. Eluting buffers were $50 \mathrm{mM}$ sodium phosphate, $0.1 \mathrm{M}$ sodium chloride, $0.1 \%$ bovine albumin, $\mathrm{pH} 7.0$ (left), and the same buffer at $\mathrm{pH}$ 3.0 (right). The flow rate was $0.5 \mathrm{ml} / \mathrm{min}$. The absorbance, at $280 \mathrm{~nm}$ (solid line), is taken directly from a recorder tracing. The IR-BP (solid circles and hatched areas) was measured on $10-\mu 1$ aliquots of each 0.5 $\mathrm{ml}$ fraction. Arrows indicate the void volume (Vo) and the elution positions of molecular weight markers: guinea pig gamma globulin (150 $\mathrm{kD})$, bovine albumin (67 kD), ovalbumin (43 kD), and trypsinogen (24 kD). 


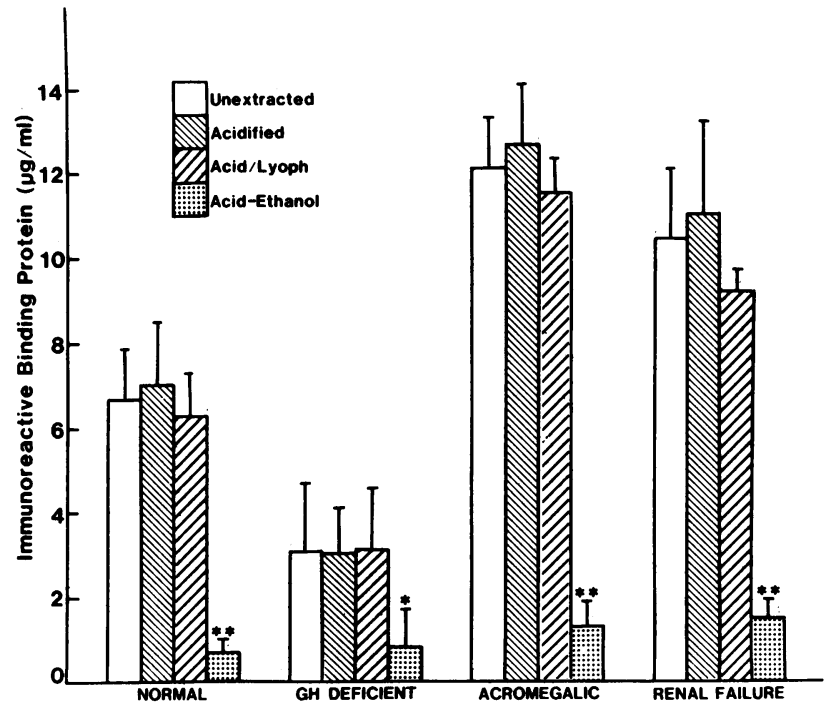

Figure 4. IR-BP in plasma samples that were either untreated, acidified with $1 \mathrm{M}$ acetic acid and then neutralized, acidified with $1 \%$ formic acid and then lyophilized and reconstituted in buffer (Acid/ Lyoph), or extracted with acidified ethanol according to the method of Daughaday (21), as indicated. See Methods for experimental details. Bars represent mean values \pm SD for groups of three samples each from normal subjects and from patients with GH deficiency, acromegaly, and chronic renal failure. Differences ( $t$ test) from corresponding unextracted group: $* P=0.05 ; * * P<0.001$; other differences not significant.

normal $(P<0.02)$, acromegalic $(P<0.01)$, and uremic $(P$ $<0.005$ ) samples.

The following human proteins and peptides showed $0.01 \%$ or less cross-reactivity by weight compared with the pure BP standard: transferrin, luteinizing hormone, growth hormone, placental lactogen, follicle stimulating hormone, prolactin, insulin, IGF-I, and IGF-II. A preparation of amniotic fluid BP purified in this laboratory showed $0.16 \%$ cross-reactivity. Crossreaction by human serum albumin was only $0.0005 \%$. The same specificity towards these proteins and peptides was seen when iodinated BP was used as tracer. The cross-reactivity of serum from a variety of placental and marsupial mammalian species is illustrated in Fig. 5. Among the placentals, samples from the higher primate families (macaque, mandrill, baboon, chimpanzee, and orangutan) all showed similar immunoreactivity to human plasma. In contrast, the lower primates (lemur and spider monkey) showed only marginal reactivity, and nonparallelism with human plasma, similar to that seen for two marsupial species (kangaroo and Tasmanian devil) and a variety of nonprimate placental mammals. This marginal displacement, which may represent a nonspecific effect of serum proteins, was negligible at $0.25 \mu$ l, the sample size used in the routine assay.

Plasma IR-BP in healthy subjects showed strong age dependence. Levels in young children were low $(2.42 \pm 0.74 \mu \mathrm{g} / \mathrm{ml}$ in subjects up to $3 \mathrm{yr}$ old), rising with increasing age until the end of puberty, to peak in the 14- to 15 -yr-old group at $8.23 \pm 1.62$ $\mu \mathrm{g} / \mathrm{ml}$ (Fig. 6). Sufficient samples were available from subjects aged 7-17 yr to allow analysis by sex in this age range. In children entering puberty, IR-BP rose slightly earlier in females than in males, though the difference was significant only in the 10-11age group $(P<0.001)$. After puberty, a gradual decline was seen in subjects aged $18-65$, which was significant by analysis of vari-

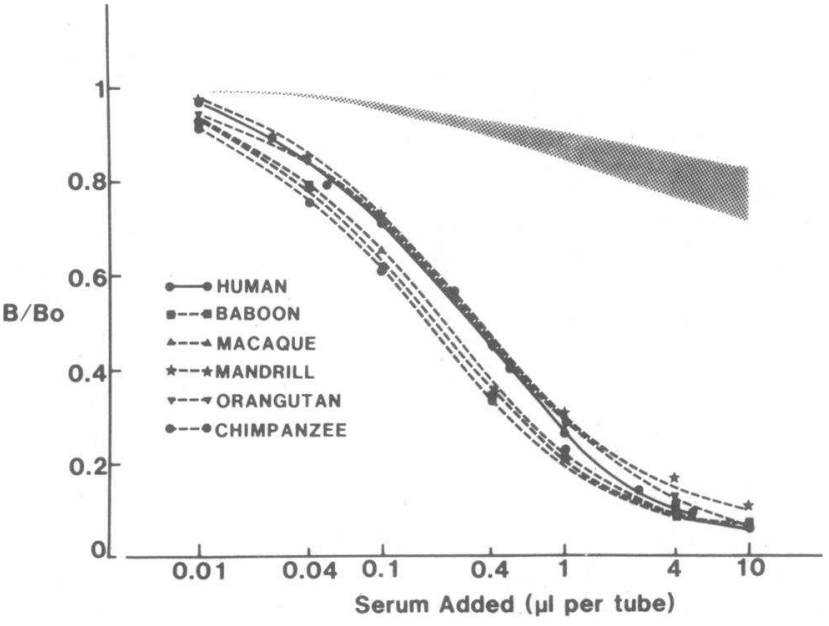

Figure 5. Species cross-reactivity of the BP RIA. Serum from the species indicated (lemur, spider monkey, cat, dog, horse, pig, sheep, rat, mouse, guinea pig, kangaroo, and Tasmanian devil, and also the higher primate species [indicated by individual symbols on the figure]) was tested at up to $10 \mu \mathrm{l}$ per tube under standard RIA conditions. Only the higher primate species showed significant cross-reactivity. The stippled area indicates the range of response seen for the remaining species tested. B/Bo is defined in the legend to Fig. 2.

ance $(P<0.005)$. The mean plasma IR-BP for 65 adults aged $18-65 \mathrm{yr}$ was $6.12 \pm 1.43 \mu \mathrm{g} / \mathrm{ml}$. Fig. 7 shows the relationship between plasma BP levels and IGF-I levels in 64 children aged $7-17 \mathrm{yr}$, and in 62 adults aged 18-65 yr, for whom both IGF-I and IGF-II levels had been measured. Highly significant associations between BP and IGF-I were seen in both cases $(r=0.731$ for children, $r=0.707$ for adults). When the sum of IGF-I and IGF-II concentrations were correlated with BP levels, similar high associations were seen $(r=0.742$ for children, $r=0.605$ for adults). In contrast, much weaker associations were seen between BP and plasma IGF-II levels alone ( $r=0.320$ for children, $r=0.434$ for adults).

In a preliminary study (15), IR-BP levels were found to show strong GH dependence. This is illustrated in greater detail in Fig. 8. The mean IR-BP level for subjects with active acromegaly was 2.2-fold higher than for normal adults, and a significant correlation was found between individual plasma IGF-I and BP levels in the acromegalic group $(r=0.580, P<0.005, n=20)$. GH deficiency was associated with significantly reduced IR-BP.

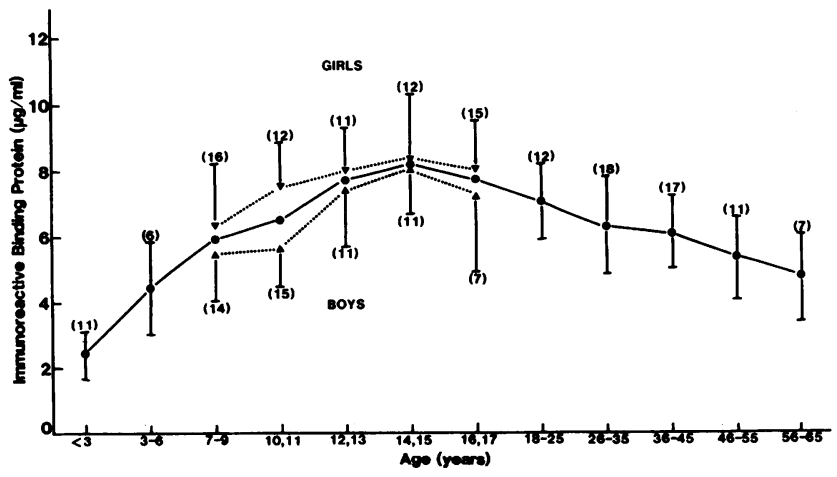

Figure 6. Age dependence of plasma IR-BP in healthy subjects. Values shown are means \pm SD for the number of subjects in parentheses. In the age range of 7 to $17 \mathrm{yr}$, individual mean data, joined by dotted lines, are shown for girls (v) and boys (४). 


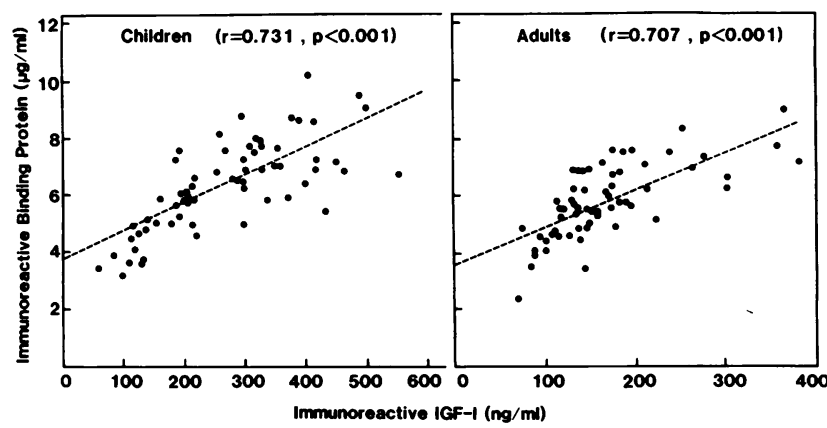

Figure 7. Relationship between IR-BP and IGF-I in 64 children aged from 7 to $17 \mathrm{yr}$ (left), and 62 adults aged from 18 to $65 \mathrm{yr}$ (right). The regression equations are: $y=3.77+0.010 x$ (children), and $y=3.58$ $+0.013 \mathrm{x}$ (adults), with correlation coefficients $(r)$ as indicated.

When compared with age-matched control groups, the reduction was $\sim 50 \%$ in GH-deficient young children and adults, whereas in a late pubertal group a decrease of almost $80 \%$ was seen. Although these age-related differences may simply reflect the particular patient samples available for analysis, it is clear that the BP RIA reflects GH status over a wide age range.

Fig. 9 illustrates BP levels in plasma from subjects with hypothyroidism, diabetes, and renal failure, and in plasma and amniotic fluid from pregnant women. Although the mean level in hypothyroid subjects, $5.05 \pm 1.20 \mu \mathrm{g} / \mathrm{ml}$, was slightly lower than the normal adult mean $(P<0.02)$, it was not significantly different from the mean for a control group aged 36-65 yr $(5.72 \pm 1.29 \mu \mathrm{g} / \mathrm{ml}, n=34)$. Correlations between IR-BP and plasma thyroxine, and between IR-BP and thyrotropin stimulating hormone, in individual subjects, were not statistically significant ( $r=-0.024$, and $r=-0.298$, respectively). In a group of patients attending the Diabetes Outpatients' Clinic at this hospital, who were selected only for their hemoglobin A1c levels $(>11 \%)$, there was a $40 \%$ decrease in mean BP levels to $3.78 \pm 1.90$ $\mu \mathrm{g} / \mathrm{ml}$, significantly lower than the group means for normal subjects aged $18-65$ or $36-65$ yr $(P<0.001)$. However, the low BP levels in diabetes did not appear to relate directly to the state of diabetic control in these patients, as BP and hemoglobin Alc values in individuals did not show a significant association $(r$ $=0.032$ ). Chronic renal failure was associated with a $33 \%$ increase in IR-BP above the normal mean $(P<0.001)$. In thirdterm pregnancy, a significant elevation in BP levels, to $11.24 \pm 3.13 \mu \mathrm{g} / \mathrm{ml}$, was seen $(P<0.001)$. Finally, the mean IRBP level in amniotic fluid was $7.18 \pm 2.03 \mu \mathrm{g} / \mathrm{ml}$, which was similar to normal plasma values.

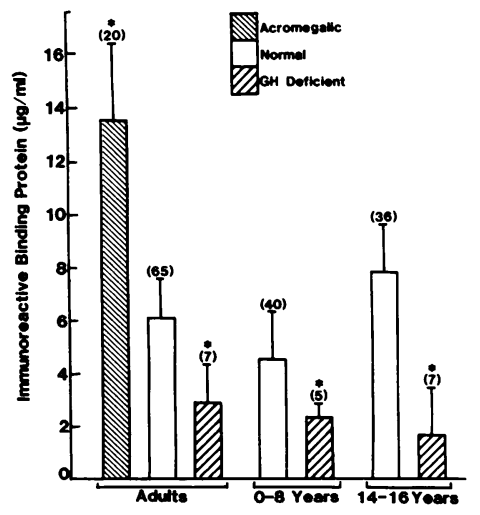

Figure 8. IR-BP in plasma from normal, GH-deficient, and acromegalic subjects, as indicated. Data shown are means \pm SD for numbers in parentheses. Normal values are shown for each of the three age ranges indicated. Comparisons ( $t$ test) with age-matched normals: $* P$ $<0.001$.

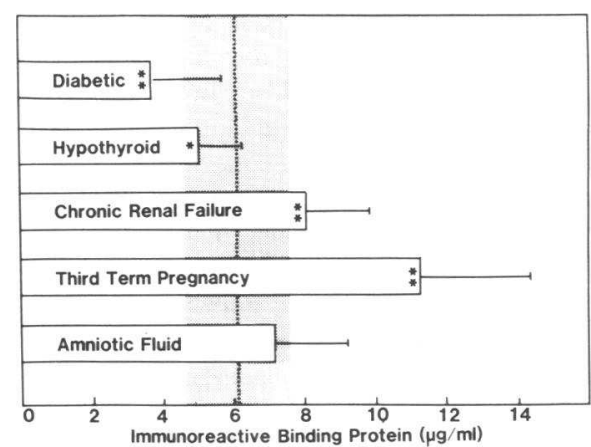

Figure 9. IR-BP in plasma from pregnant subjects and adult patients with diabetes mellitus, hypothyroidism, and chronic renal failure, and in amniotic fluid. Values shown are means \pm SD for 10 samples in each group. The shaded area represents the mean \pm 1 SD for 65 normal subjects aged from 18 to 65 . Comparisons ( $t$ test) with normal means: $* P$ $<0.02 ; * * P<0.001$.

\section{Discussion}

Before the establishment of the radioimmunoassay for the GHdependent IGF binding protein described in this report, it was only possible to measure this protein by ligand binding. Such studies have been performed both on unacidified samples $(3,4)$ and after fractionating samples at low pH (10-12). Both approaches have inherent disadvantages. In the absence of acidification, binding of radioactive ligands, with or without covalent cross-linking, may be severely affected by the presence of endogenous IGFs, most of which are carried in the circulation bound to this protein $(4,5,22)$. This problem is overcome if samples are acidified and fractionated by gel chromatography at low pH before assay, but this procedure results in the irreversible breakdown of the native binding complex to yield binding species in the $50-60 \mathrm{kD}$ range $(13,14)$. In the present study, these disadvantages have been overcome by using an antibody raised against the 53-kD acid-stable $\mathrm{BP}$, which detects the socalled $150-\mathrm{kD}$ complex almost exclusively in native plasma (15).

In practice, the apparent molecular mass of the main immunoreactive species in native plasma appears smaller than 150 $\mathrm{kD}$ in the present study, in which a Superose 12 high performance column was used instead of the Sephacryl S-200 used previously (15). Comparison with the elution volumes of standard proteins indicates a molecular mass of $\sim 125 \mathrm{kD}$. Molecular mass estimates of this complex vary in different studies from 100 to 150 $\mathrm{kD}(4,23,24)$, as determined by gel filtration, whereas the study of Wilkins and D'Ercole (7), involving affinity labeling and polyacrylamide gel electrophoresis indicated bands corresponding to 110,135 , and $160 \mathrm{kD}$. This study also found affinitylabeled complexes of $24-28,50$, and $80 \mathrm{kD}$ (7). These species may be present in the relatively small "shoulder" of BP immunoreactivity that elutes after the $125-\mathrm{kD}$ peak. The species described as 24 and $28 \mathrm{kD}$ are particularly interesting, as they may correspond to the recently described complexes of 21.5 and $25.5 \mathrm{kD}(25)$ formed by affinity labeling an IGF inhibitor preparation from human plasma, of a molecular mass of $16-18 \mathrm{kD}$ (26). This inhibitor preparation, kindly provided by Dr. A. C. Herington, Medical Research Center, Prince Henry's Hospital, Melbourne, Australia, shows very strong activity in our BP RIA (unpublished observation), which indicates a structural relationship to the 53-kD BP. However, there was little or no immunoreactivity corresponding to $16-18 \mathrm{kD}$ when we fractionated 
fresh serum on a Superose 12 column, which suggested that this may not represent a significant BP species in the circulation. Therefore, it must be concluded at present that the size distribution of IGF BPs will depend on the analytical method used.

In acidified plasma chromatographed at pH 3, the BP immunoreactivity was mostly in the $55-60 \mathrm{kD}$ range, with a significant second component of $25-30 \mathrm{kD}$. It seems probable that the major peak represents the $53-\mathrm{kD}$ protein that we have purified and used as a standard, to prepare tracer, and to raise the antibody in the present study. The origin of the $25-30-\mathrm{kD}$ component is not yet clear, but it may contain the IGF inhibitor (26) referred to above or correspond to the BP that can be detected by affinity labeling in the $30-45-\mathrm{kD}$ region after exposure of plasma to buffer at $\mathrm{pH} 3.6$ (7). This has been postulated to result from acidification damage to $35-43-\mathrm{kD}$ complexes (7), but it is also possible that a BP of this size could be derived from the $53-\mathrm{kD}$ protein, as we have shown that prolonged storage of this preparation in acid results in the appearance of a $26-\mathrm{kD}$ species (16).

Whatever the exact nature of the acid-breakdown products of the native $\mathrm{BP}$, there is no change in immunoreactivity on acidification, as indicated by treatment of normal plasma or samples from GH-deficient, acromegalic, and renal failure patients, all conditions in which the size distribution of IGF binding species in plasma is known to differ from normal $(4,15,27)$. The acidification and lyophilization procedure introduced by Bala and Bhaumick (20) to minimize BP interference in the IGF-I RIA also failed to reduce the IR-BP in any plasma samples, although it may have altered the binding properties of the protein. However, the acid-ethanol extraction method of Daughaday et al. (21) was highly effective in depleting plasma of BP although, notably, there was significant residual BP in all but the GHdeficient samples.

The BP RIA is somewhat unusual in that it uses as tracer a covalent complex of radioiodinated IGF-I and BP, rather than iodo-BP itself. This was done for purely technical reasons, since the iodinated protein tended to adsorb to plastic tubes and gave unacceptably high nonspecific binding when used as a tracer. These problems were avoided when using the cross-linked tracer, which suggested that the region of the BP responsible for its tendency to stick to plastic might be at or near the IGF-binding region. It may also be, however, that the occupancy of its binding site by IGF-I confers other advantages on the BP, such as enhancing its stability. It certainly appeared that, when not iodinated, occupied BP (for example, in native plasma) was much more stable than the purified, ligand-depleted BP used as a standard. The apparent instability of pure BP was seen most notably in Hepes and certain other organic sulfonate buffers, in which a marked nonparallelism with whole plasma BP was seen in the RIA.

The mean IR-BP level in normal adults, $6.12 \pm 1.43 \mu \mathrm{g} / \mathrm{ml}$, is $35 \%$ lower than the figure of $9.2 \mu \mathrm{g} / \mathrm{ml}$ that we reported in a preliminary study (15). The reason for this difference is the slightly lower potency of the standard used in the earlier study, resulting from the instability problems referred to above, and since overcome. If the immunoreactive binding subunit of the native BP complex has a molecular mass of $53 \mathrm{kD}$, the mean circulating BP concentration is equivalent to $115 \mathrm{nmol} / \mathrm{liter}$. This is almost identical to the sum of circulating IGF-I and IGFII concentrations, since the mean level of IGF-I, measured in several laboratories, is $200-250 \mathrm{ng} / \mathrm{ml}$, or $\sim 30 \mathrm{nmol} /$ liter, and of IGF-II, $570-660 \mathrm{ng} / \mathrm{ml}$, or $\sim 85 \mathrm{nmol} /$ liter (28). This may indicate that a specific mechanism exists to regulate BP production according to the available IGFs, or in coordination with IGF synthesis, as we have previously shown that in the rat (which has very little circulating IGF-II), the liver produces IGF-I and BP in essentially equimolar amounts (29). An alternative explanation is that the total concentration of circulating IGFs is determined at least in part by the availability of binding sites, as the free peptides are thought to have circulating half-lives of only $8 \mathrm{~min}$, compared with $3 \mathrm{~h}$ when protein bound (30).

Both age dependence and GH dependence of BP, demonstrated in this study by RIA, have been previously observed using ligand-binding methods. Binoux et al. (12), measuring IGF-I binding to acid-chromatographed serum, found slightly lower values in early childhood and elevated values in puberty, which is similar to the present results. A significant correlation was also seen between IGF levels, measured by competitive binding assay using rat liver $\mathrm{BP}$, and binding activity in normal subjects. GH dependence of 150-kD BP has been shown in several studies in which whole serum or plasma from subjects with $\mathrm{GH}$ disorders was incubated with IGF-I or IGF-II tracer before gel chromatography at neutral $\mathrm{pH}(3,4)$, and affinity labeling of BP species of $24,28,50$, and $80 \mathrm{kD}$ also varies according to $\mathrm{GH}$ status (7). Ligand-binding assays using acid-chromatographed samples also tend to show GH dependence $(11,12)$, although in one such study no elevation was seen in acromegaly (10). When measured by our BP RIA, acromegalic subjects had BP levels elevated more than twofold, while significant decreases were seen in GHdeficient subjects in various age groups. This contrasts with the inverse GH dependence reported for the plasma BP species detected by the amniotic fluid BP RIA (6). Note that, if circulating IGF levels are determined by binding site availability, as suggested above, the so-called "partial GH dependence" of IGF-II, where circulating levels are reduced in GH deficiency but not elevated in acromegaly (17), could in fact be explained simply by the decreased BP levels seen in GH deficiency and a constant, $\mathrm{GH}$-independent production of IGF-II.

Variations in IR-BP levels were also seen in the several clinical conditions examined. The apparent slight decrease in hypothyroidism disappeared when values were compared with agematched controls, despite the fact that IGF-I levels are known to be reduced in this condition (19). The reduction in BP seen in adult diabetics with poor control is consistent with our observations of decreased IGF-I levels (28), although, as recently reviewed (28), a variety of other studies show no change in IGFI, or even an increase. Ligand-binding measurements of BP in diabetic subjects also show reduced levels, which were consistent with our RIA measurements $(10,31)$. However, in contrast to the study of Rieu and Binoux (31), we saw no correlation between the degree of diabetic control and BP levels in individual patients.

Renal failure was associated with elevated BP levels, which was also observed previously by direct IGF-II binding to whole serum (27). However, in the study of Goldberg et al. (27), this was accompanied by a decrease in the molecular weight of the binding species. The question of the size of IR-BP in renal failure has not been addressed in the present study, but the $35-\mathrm{kD}$ serum protein that cross-reacts in the amniotic fluid BP RIA is also known to increase in renal failure $(6,32)$, so that increased ligand binding in the lower molecular weight region might be to this protein. Since IGF-I is reduced in renal failure $(18,27)$, the additional binding sites in this condition, possibly resulting from 
reduced renal clearance of the various BP species, might in part account for the elevated IGF-II levels seen in several studies (17, 27), as the circulating half-life of this peptide would effectively be increased by the longer half-life of the binding proteins.

In late pregnancy, IR-BP levels were elevated almost twofold. A similar increase is also seen in the $35-\mathrm{kD}$ BP using the amniotic fluid BP RIA (32). This parallels a rise known to occur in IGFI levels $(32,33)$ that is independent of maternal $\mathrm{GH}$ production (33). It has previously been suggested that placental lactogen might act as a GH analogue in pregnancy (34), but it is unlikely that this would be responsible for induction of the $35-\mathrm{kD}$ protein which, if anything, is decreased in states of GH excess (6). It may be, however, that placental lactogen can act as an inducer of the GH-dependent IR-BP measured in the present study.

The most marked contrast between the amniotic fluid BP RIA and the assay described here is seen when measuring BP in amniotic fluid samples. Levels 50-200 times above the serum concentration have been found by the amniotic fluid BP assay (9), whereas the present assay showed no elevation compared with plasma levels. The BP detected in amniotic fluid in the present study is clearly different from that measured with the amniotic fluid BP assays, as we showed directly that a BP isolated from amniotic fluid in this laboratory with an amino terminus identical to that reported for the previously isolated $35-\mathrm{kD}$ protein had $<0.2 \%$ cross-reactivity in our assay. Whether this is due to minor contamination of our preparation by $53-\mathrm{kD} \mathrm{BP}$ or a related protein is not known. In any case, this level of crossreactivity could not account for the IR-BP measured in amniotic fluid using our RIA ( $\sim \mu \mathrm{g} / \mathrm{ml})$, as the mean level of $35-\mathrm{kD}$ BP in amniotic fluid is reported to be $\sim 150 \mu \mathrm{g} / \mathrm{ml}$ (9). Since the 35-kD plasma BP species is immunologically related to the amniotic fluid protein (8), it is also unlikely that our assay detects this protein in plasma samples.

In conclusion, a variety of data indicate that the BP species measured by the different assays are not only different in molecular mass and immunoreactivity, but may be under entirely different regulation, despite similarities seen in renal failure and pregnancy. The physiological relationship between the various circulating BP species is at present unknown. Since the protein of molecular mass $35 \mathrm{kD}$ is regulated by $\mathrm{GH}$ in an inverse manner to the high molecular mass complex, it is possible that it combines, under GH control, with other proteins to become part of the GH-dependent complex, leaving a reduced concentration of the $35 \mathrm{kD}$ form. This hypothesis is given some credence by the recent report that a plasma protein with an amino-terminal sequence similar to that of the amniotic fluid BP is found in the $150-\mathrm{kD}$ complex (35). It is not at all clear, however, what the function of such a mechanism might be. Further radioimmunological studies of the distribution of the various BP species in the circulation should help to resolve this question.

\section{Acknowledgments}

Some of the samples used in this study were generously provided by the Red Cross Blood Bank, Sydney; Drs. G. Warne and G. Werther, Royal Children's Hospital, Melbourne; Dr. C. Cowell, Royal Alexandra Hospital for Children, Sydney; Dr. D. Church, Department of Veterinary Clinical Studies, University of Sydney; and the Departments of Biochemistry, Renal Medicine, and Obstetrics and Gynecology, Royal Prince Alfred Hospital, Sydney. IGF-I and IGF-II assays were performed by K. Tan and J. De Mellow.

This work was supported by the National Health and Medical Research Council, Australia.

\section{References}

1. Kaufmann, U., J. Zapf, B. Toretti, and E. R. Froesch. 1977. Demonstration of a specific serum carrier protein of nonsuppressible insulinlike activity in vivo. J. Clin. Endocrinol. Metab. 44:160-166.

2. Hintz, R. L., and F. Liu. 1977. Demonstration of specific protein binding sites for somatomedin. J. Clin. Endocrinol. Metab. 45:988-995.

3. White, R. M., S. P. Nissley, A. C. Moses, M. M. Rechler, and R. E. Johnsonbaugh. 1981. The growth hormone dependence of a somatomedin-binding protein in human serum. J. Clin. Endocrinol. Metab. 53:49-57.

4. Hintz, R. L., F. Liu, R. G. Rosenfeld, and S. F. Kemp. 1981. Plasma somatomedin-binding proteins in hypopituitarism: changes during growth hormone therapy. J. Clin. Endocrinol. Metab. 53:100-104.

5. Daughaday, W. H., A. P. Ward, A. C. Goldberg, B. Trivedi, and M. Kapadia. 1982. Characterization of somatomedin binding in human serum by ultracentrifugation and gel filtration. J. Clin. Endocrinol. Metab. 55:916-921.

6. Povoa, G., A. Roovete, and K. Hall. 1984. Cross-reaction of a serum somatomedin-binding protein in a radioimmunoassay developed for somatomedin-binding protein isolated from human amniotic fluid. Acta Endocrinol. 107:563-570.

7. Wilkins, J. R., and A. J. D'Ercole. 1985. Affinity-labeled plasma somatomedin-C/insulinlike growth factor I binding protein. J. Clin. Invest. $75: 1350-1358$.

8. D'Ercole, A. J., S. L. S. Drop, and D. J. Kortleve. 1985. Somatomedin-C/insulin-like growth factor I-binding proteins in human amniotic fluid and in fetal and postnatal blood: evidence for immunological homology. J. Clin. Endocrinol. Metab. 61:612-617.

9. Drop, S. L. S., D. J. Kortleve, and H. J. Guyda. 1984. Isolation of a somatomedin-binding protein from preterm amniotic fluid. Development of a radioimmunoassay. J. Clin. Endocrinol. Metab. 59:899907.

10. Zapf, J., B. Morell, H. Walter, Z. Laron, and E. R. Froesch. 1980. Serum levels of insulin-like growth factor (IGF) and its carrier protein in various metabolic disorders. Acta Endocrinol. 95:505-517.

11. Schalch, D. S., S. E. Tollefsen, G. J. Klingensmith, R. W. Gotlin, and M. J. Diehl. 1982. Effects of human growth hormone administration on serum somatomedins, somatomedin carrier proteins, and growth rates in children with growth hormone deficiency. J. Clin. Endocrinol. Metab. 55:49-55.

12. Binoux, M., D. Seurin, C. Lassarre, and M. Gourmelen. 1984. Preferential measurement of insulin-like growth factor (IGF) I-related peptides in serum with the aid of IGF binding proteins (IGF BPs) produced by rat liver in culture. Estimation of serum IGF BP levels. J. Clin. Endocrinol. Metab. 59:453-462.

13. Furlanetto, R. W. 1980. The somatomedin C binding protein: evidence for a heterologous subunit structure. J. Clin. Endocrinol. Metab. 51:12-19.

14. Morris, D. H., and D. S. Schalch. 1982. Structure of somatomedinbinding protein: alkaline $\mathrm{pH}$-induced dissociation of an acid-stable 60,000 molecular weight complex into smaller components. Endocrinology. 111: 801-805.

15. Martin, J. L., and R. C. Baxter. 1985. Antibody against acidstable insulin-like growth factor binding protein detects $150,000 \mathrm{~mol} \mathrm{wt}$ growth hormone-dependent complex in human plasma. J. Clin. Endocrinol. Metab. 61:799-801.

16. Martin, J. L., and R. C. Baxter. 1986. Insulin-like growth factor binding protein from human plasma: purification and characterization. J. Biol. Chem. 261:8754-8760.

16a. Baxter, R. C., J. L. Martin, M. I. Tyler, and M. E. H. Howden. 1986. Growth hormone-dependent insulin-like growth factor (IGF) binding protein from human plasma differs from other human IGF binding proteins. Biochem. Biophys. Res. Commun. 139:1256-1261.

17. Baxter, R. C., and J. S. M. De Mellow. 1986. Measurement of insulin-like growth factor-II by radioreceptor assay using ovine placental membranes. Clin. Endocrinol. 24:267-278. 
18. Povoa, G., G. Enberg, H. Jornvall, and K. Hall. 1984. Isolation and characterization of a somatomedin-binding protein from mid-term amniotic fluid. Eur. J. Biochem. 144:199-204.

19. Baxter, R. C., A. S. Brown, and J. R. Turtle. 1982. Radioimmunoassay for somatomedin-C: comparison with radioreceptor assay in patients with growth hormone disorders, hypothyroidism, and renal failure. Clin. Chem. 28:488-495.

20. Bala, R. M., and B. Bhaumick. 1979. Radioimmunoassay of a basic somatomedin: comparison of various assay techniques and somatomedin levels in various sera. J. Clin. Endocrinol. Metab. 49:770777.

21. Daughaday, W. H., I. K. Mariz, and S. L. Blethen. 1980. Inhibition of access of bound somatomedin to membrane receptor and immunobinding sites: a comparison of RRA and RIA of somatomedin in native and acid ethanol-extracted serum. J. Clin. Endocrinol. Metab. 51:781788.

22. Furlanetto, R. W., L. E. Underwood, J. J. Van Wyk, and A. J. D'Ercole. 1977. Estimation of somatomedin-C levels in normals and patients with pituitary disease by radioimmunoassay. J. Clin. Invest. 60: 648-657.

23. Hall, K., J. Brandt, G. Enberg, and L. Fryklund. 1979. Immunoreactive somatomedin A in human serum. J. Clin. Endocrinol. Metab. 48:271-278.

24. Copeland, K. C., L. E. Underwood, and J. J. Van Wyk. 1980. Induction of immunoreactive somatomedin $\mathrm{C}$ in human serum by growth hormone: dose-response relationships and effect on chromatographic profiles. J. Clin. Endocrinol. Metab. 50:690-697.

25. Ooi, G. T., and A. C. Herington. 1986. Covalent cross-linking of insulin-like growth factor-I to a specific inhibitor from human serum. Biochem. Biophys. Res. Commun. 137:411-417.

26. Kuffer, A. D., and A. C. Herington. 1984. Partial purification of a specific inhibitor of the insulin-like growth factors by reversed-phase high-performance liquid chromatography. J. Chromatogr. 336:87-92.

27. Goldberg, A. C., B. Trivedi, J. A. Delmez, H. R. Harter, and W. H. Daughaday. 1982. Uremia reduces serum insulin-like growth factor-I, increases insulin-like growth factor-II, and modifies their serum protein binding. J. Clin. Endocrinol. Metab. 55:1040-1045.

28. Baxter, R. C. 1986. The somatomedins: insulin-like growth factors. Adv. Clin. Chem. 25:49-115.

29. Scott, C. D., J. L. Martin, and R. C. Baxter. 1985. Production of insulin-like growth factor-I and its binding protein by adult rat hepatocytes in primary culture. Endocrinology. 116:1094-1101.

30. Cohen, K. L., and S. P. Nissley. 1976. The serum half-life of somatomedin activity: evidence for growth hormone dependence. Acta Endocrinol. 83:243-258.

31. Rieu, M., and M. Binoux. 1985. Serum levels of insulin-like growth factor (IGF) and IGF binding protein in insulin-dependent diabetics during an episode of severe metabolic decompensation and the recovery phase. J. Clin. Endocrinol. Metab. 60:781-785.

32. Drop, S. L. S., D. J. Kortleve, H. J. Guyda, and B. I. Posner. 1984. Immunoassay of a somatomedin-binding protein from human amniotic fluid: levels in fetal, neonatal and adult sera. J. Clin. Endocrinol. Metab. 59:908-915.

33. Hall, K., G. Enberg, E. Hellem, G. Lundin, A. Ottoson-Seeberger, V. Sara, O. Trystad, and U. Ofverholm. 1984. Somatomedin levels in pregnancy: longitudinal study in healthy subjects and patients with growth hormone deficiency. J. Clin. Endocrinol. Metab. 59:587-594.

34. Merimee, T. J., J. Zapf, and E. R. Froesch. 1982. Insulin-like growth factor in pregnancy: studies in a growth hormone deficient dwarf. J. Clin. Endocrinol. Metab. 54:1101-1103.

35. Enberg, G. 1986. Purification of a high molecular weight somatomedin binding protein from human plasma. Biochem. Biophys. Res. Commun. 135:178-182. 